Article

\title{
Cross Road Elections: Change in EU Performance Evaluations during the European Parliament Elections 2014
}

\author{
Claes de Vreese *, Rachid Azrout and Judith Moeller \\ Amsterdam School of Communication Research ASCoR, University of Amsterdam, 1018 WV Amsterdam, \\ The Netherlands; E-Mails: c.h.devreese@uva.nl (C.V.), R.Azrout@uva.nl (R.A.), J.E.Moller1@uva.nl (J.M.) \\ * Corresponding author
}

Submitted: 2 October 2015 | Accepted: 18 December 2015 | Published: 29 February 2016

\begin{abstract}
The 2014 European Parliament (EP) elections were held after a period where public opinion about the EU changed significantly. In this paper we investigate evaluations of the performance of the European Union, as this dimension of EU attitudes is particularly relevant ahead of elections. We look at public opinion developments since 2009 and then zoom in on the role played by the news media in shaping public opinion about EU performance by linking citizens' evaluations across time to the news media content they were exposed to. The article relies on original multiple wave survey panel data and a systematic media content analysis in the Netherlands. It shows how public opinion has changed, how it changes around EP elections, and how exposure to media coverage can help improve citizens' evaluations of EU performance.
\end{abstract}

\section{Keywords}

EU attitudes; European Parliament elections; media effects; public opinion

\section{Issue}

This article is part of the issue "How Different Were the European Elections of 2014?", edited by Wouter van der Brug, Katjana Gattermann and Claes de Vreese (University of Amsterdam, The Netherlands).

(C) 2016 by the authors; licensee Cogitatio (Lisbon, Portugal). This article is licensed under a Creative Commons Attribution 4.0 International License (CC BY).

\section{Introduction}

The 2014 European Parliament (EP) elections were among the most contested in the history of the European Union. Never before were elites and citizens so divided on EU questions and never before were anti-EU sentiments so strong. For a long time European integration was considered a consensus topic (Hooghe \& Marks, 2005) and EU attitudes were seen as uni-dimensional. This made intuitive sense during a period where European integration was rarely politicized and the EU did not feature centrally in political or public debates. Recent work in the field, however, demonstrated that these attitudes contain multiple dimensions (Hobolt, 2014). Boomgaarden, Schuck, Elenbaas and de Vreese (2011) identified five dimensions dealing with (1) the identification with Europe, (2) evaluations of potential benefits of the EU, (3) evaluations of the current (democratic) performance of the EU, (4) the emotional component of attitudes towards the EU, and finally (5) a more ideological attitude towards EU integration. This dimensional structure has been validated and the importance of these dimensions for voting behaviour in EP elections has been demonstrated (van Spanje \& de Vreese, 2014).

In this paper we focus in particular on the performance dimension of EU attitudes. The perceived performance of the European Union and its institutions is highly relevant in relation to elections where citizens are asked to vote for one of the key institutions, because it is one of the most important criteria voters apply in order to make their voting decisions. Indeed a rich literature has shown that citizens are capable of evaluating the performance of their elected officials, also in the context of EU politics (Tilley \& Hobolt, 2011). Moreover, 
performance evaluations are a key component of citizens' general evaluations of EU politics (de Vreese \& van der Brug, 2016).

In this study, we first look at how this dimension of EU attitudes has developed at the aggregate level since 2009. Second, we turn to the individual level and investigate the role played by the news media in shaping public opinion about EU performance by linking citizens' evaluations across time to the news media content they were exposed to. Using multiple wave panel survey data and a media content analysis, the central question is if exposure to news about the performance of the EU affects change in individual level attitudes.

Understanding these dynamics is important, both from a theoretical point of view of trying to understand the role of new information in shaping EU attitudes as well as from a societal point of view, as the EU is a political reality that has been very prominent in past years' politics. But this increase in prominence was paralleled by an increase in the contentiousness of the EU, and the obviousness of the EU is not undisputed. Understanding support for the EU is important for the legitimacy (or illegitimacy) of the EU as a democratic system. Furthermore these findings may help us in understanding citizens' decisions to vote for pro-European or Eurosceptic parties (see Treib, 2014; van Spanje \& de Vreese, 2014). In the long run EU attitudes and voting based on EU considerations may affect not only the direction in which the EU is heading, but also national political choices (de Vries, 2007).

\section{EU Attitudes: Multiple Dimensions}

The EU today covers more policy areas and more geographical space than ever before. As argued in detail elsewhere, there are very good theoretical and empirical reasons to consider EU attitudes as multidimensional. In general, political support can be directed towards different objects of support (Easton, 1975), can be diffuse or specific (Gabel, 1998; Hewstone, 1986), or can be of a utilitarian or affective nature (Lindberg \& Scheingold, 1970). Recent research identified five dimensions of EU attitudes: negative affection, identity, performance, utilitarianism, and strengthening.

The first dimension, negative affection towards the $E U$, touches on a perceived threat of European unification. The second dimension, identity, encompasses attitudes specific to citizens' identification with the EU, such as pride in being an EU citizen and feeling close to other Europeans and their culture and history, but also adherence to EU symbols such as the flag. The third dimension relates to the democratic and financial functioning and the performance of European institutions, and is labelled 'performance' (of the EU). The fourth dimension, utility, entails traditional general support as well as the perception of the country's and the individual's personal benefit as a result of EU membership, and attitudes in line with post-materialist utilitarian approach to European integration in terms of the EU helping to preserve peace, prosperity and the environment. The fifth dimension called (EU) 'strengthening' entails attitudes towards the future of European integration and to a process of further deepening and widening of the EU. Within this multi-dimensional structure some sub-dimensions are more stable than others. Identity, for example, is conceptually close to being a character trait, while performance evaluations are more likely to fluctuate over time, as the actual performance of the EU is not stable itself. More importantly, mediated information about the performance of the EU varies substantially across time, depending on issue cycles and the larger political agenda, as well as the functioning of the EU institutions. For this reason and given the importance of this attitude dimension in electoral decision-making, we study performance evaluation as an outcome of exposure to EU news in detail.

\section{Doing Well? EU Performance Evaluations}

In the run up to elections it is essential that citizens form evaluations about the performance of power holders, policies, and institutions. As convincingly pointed out by Hobolt (2012), though there is a rich academic literature on how EU institutions function and how they could be designed to alleviate the alleged 'democratic deficit' in the EU, we still have only limited knowledge about how citizens view European democracy. Previous research has demonstrated that there is a lot of cross-national and individual level variation in citizens' evaluations of the democratic performance of the EU (e.g., Desmet, van Spanje, \& de Vreese, 2012). In a general sense, Alvarez and Franklin (1994) argued that how people see the performance of a regime depends on the cost-benefit assessments people make. These assessments may pertain to evaluations of political performance (Klingemann \& Fuchs, 1995; Rose \& Mishler, 2002), economic performance (Anderson \& Guillory, 1997; Lewis-Beck, 1988), and expectations of governance in the near future (Stokes, 2001).

The EU performance evaluations as part of the broader EU attitude structure are important because they concern the perception and evaluation of the actual functioning of the systems and its institutions. In line with Rohrschneider (2002), Scheuer (2005), and Boomgaarden et al. (2011), Desmet et al. (2012) found that citizens do not per se connect their evaluations of the EU's democratic performance with their political support for further integration, i.e. these are relatively independent attitude dimensions. That said, performance evaluations matter for future support as they are building blocks for these latter, more general attitudes, and they are, as such, crucial considerations in the process of EU opinion formation (Sanchez-Cuenca, 2000; Rohrschneider, 2002). 
Most prior research focusing on the EU's performance has relied on a single item tapping satisfaction with the way democracy works. This has been investigated both in general cross-national terms (e.g., Norris, 1999) and with respect to the EU specifically (Karp, Banducci, \& Bowler, 2003). Hobolt (2012) succinctly summarizes that in the "EU context, scholars have argued that whereas input-oriented and output-oriented legitimacy coexist in democratic nation-states, support for democracy in the EU must rely solely on output-based legitimacy (see, for example, Majone, 1998, 2000)". As Scharpf (1999, p. 12) notes: '[T] he legitimacy of [the EU's] institutional practices...is almost automatically judged, and found wanting, by reference to the conglomerate of input- and output-oriented criteria familiar from national debates'. As put by Hobolt (2012): "since the EU lacks a single demos with a collective identity, the legitimacy of the Union hinges almost exclusively on its performance (Scharpf, 1999; Majone, 2000)". This makes the performance dimension of EU attitudes crucial.

\section{Explaining Change in EU Performance Evaluations}

As a general antecedent of EU performance evaluations we know that economic considerations and government approval matter (the so-called national yardstick, see Boomgaarden et al., 2011; Desmet et al., 2012; Hobolt, 2012). However, since we, in this study, are concerned with changes in performance evaluations, we focus in particular on one of the key antecedents for changing opinions, the role of information as provided by the media. Research has generally not paid much attention to how media may affect citizens' assessment of the democratic performance of a polity like the EU (see Desmet, van Spanje, \& de Vreese, 2015, for an exception). This might be surprising since we know from other studies that being exposed to specific media coverage can alter perceptions and support for different EU issues (e.g., Azrout, van Spanje, \& de Vreese, 2012; de Vreese \& Boomgaarden, 2016; Maier \& Rittberger, 2008).

The functioning of the EU is an issue where most citizens rely on others' judgment-in lieu of direct, personal experiences. In the words of Desmet et al. (2015, p. 3179): "Because European citizens do not experience the democratic performance of the EU first-hand, evaluations of the democratic performance of the EU depend on collective experiences, and therefore on information gathered through interpersonal and mass media communication". We theorize that specific aspects of the media coverage are most likely to affect performance evaluations, namely visibility of the EU and evaluations of the EU by actors in the news or the editorial board (de Vreese, Banducci, Semetko, \& Boomgaarden, 2006; Hopmann, Vliegenthart, De Vreese, \& Albæk,

\footnotetext{
${ }^{1}$ Fieldwork dates were $13^{\text {th }}-26^{\text {th }}$ of December, 2013 for the first
} wave, $20^{\text {th }}-30^{\text {th }}$ of March, 2014 for the second wave, $17^{\text {th }}-28^{\text {th }}$
2010). Visibility refers to how often the EU or its institutions and actions are in the news. The visibility has traditionally been low to modest but with significant crossnational variation (e.g., de Vreese et al., 2006). The supply of information is a condition sine qua non speculating about media effects stemming from news coverage makes little sense. In addition, specific features of the coverage, evaluations of the EU in general and, in particular, evaluation of the democratic performance of the $E U$, and the quality/effectiveness of the policies of the EU are expected to affect evaluations. Because these evaluations provide a frame of reference to news users that they can apply when they make up their mind about the performance of the EU. Based on extant research our key hypothesis is that exposure to news with explicit evaluations is likely to cause change in EU performance evaluation. We address this by estimating the impact of both news visibility and evaluations on change in evaluations, and we also assess the magnitude of these effects by offering insights into what would happen with evaluations if either the news content or the news usage of individuals would change.

\section{Methods}

To test our hypothesis we rely on two original sources of data: a national four-wave panel survey and a media content analysis. Our study is conducted in the Netherlands. This country was long seen as a stable supporter of further integration, but public opinion has changed and the Dutch voted no to the Constitutional Treaty in a referendum in 2005 and in EP elections in both 2009 and 2014, Eurosceptic parties gained a significant share of the vote. This makes the Netherlands an interesting case to investigate further. Ideally, our research would have allowed us to collect multiple wave survey data and media data in more countries, but in the absence of this opportunity we also stress that our key concern is to test the dynamics of media influence on public evaluations. We are more concerned with the nature of this dynamic than with the actual level of support, and we have little reason to expect that the dynamic would be different in a different context.

\subsection{Survey}

A four-wave panel survey was held in the Netherlands, with waves in December 2013 and March, April, and May 2014. ${ }^{1}$ It is part of the '2014 European Election Campaign Study' (de Vreese, Azrout, \& Möller, 2014). The fieldwork was coordinated by TNS NIPO Netherlands, a research institute that complies with ESOMAR guidelines for survey research. The sample was drawn from the TNS NIPO database. The database consists of

of April, 2014 for the third wave, and $26^{\text {th }}$ of May- $2^{\text {nd }}$ of June, 2014 for the fourth wave. 
200,000 individuals that were recruited through multiple recruitment strategies, including telephone, face-toface, and online recruitment. Quotas (on age, gender, and education) were enforced in sampling from the database. The survey was conducted using Computer Assisted Web Interviewing (CAWI). A total of 2189 respondents participated in wave one (response rate $78.1 \%$ ), 1819 respondents participated in wave two (recontact rate $83.1 \%), 1537$ participated in wave three (re-contact rate $84.5 \%$ ), and 1379 in wave four (re-contact rate $89.7 \%$ ).

\subsection{Content Analysis}

Visibility and evaluations of the EU in the media were measured in a quantitative media content analysis of three daily newspapers (two quality newspapers [NRC Handelsblad and De Volkskrant] and one tabloid [De Telegraaf]), two television news programs (one from the public broadcaster [NOS Journaal] and one from a commercial broadcaster [RTL Nieuws]) and one widely read online news source (nu.nl). ${ }^{2}$ We sampled the news from December $2^{\text {nd }}, 2013$ until May 21 ${ }^{\text {st }}, 2014$ (the day before the EP Election Day). For the period before the EPE campaign period (until April $16^{\text {th }}$ ) every outlet was coded every $3^{\text {rd }}$ day, according to an alternating scheme (so each time a particular outlet would not be coded on a particular day of the week); during the campaign period, all outlets were coded every day.

For the newspapers, every article on the front page and on a random page was coded. In addition, during the campaign period, for every other newspaper, coders would also code all articles on the domestic and international (foreign) news pages that mentioned the EU (or its institutions or the EP elections) at least twice. In the period before the campaign, coders coded all articles mentioning the EU twice for each newspaper in our sample. For television news all stories were coded, with the exception of the weather forecast and specific sections devoted to sports.

For the online source, the sampling strategy was similar to the one used for the newspapers. Since the

\footnotetext{
${ }^{2}$ We chose these outlets because they are the most used news media in their respective categories, and together they give a good representation of the Dutch media environment. More specifically we focus on a combination of national television news and newspapers, because these media are consistently listed as the most important sources of information about the EU for citizens in Europe (Eurobarometer 54-62). We first included the main national evening news broadcasts of the most widely watched public (NOS Journaal) and commercial (RTL Nieuws) television stations. Second we included three newspapers: De Telegraaf is the most read national newspaper with a sensationalist character; De Volkskrant and NRC Handelsblad are the most read quality newspapers, with the first having a
}

front page of online news is unique for every user visiting the site at a specific point in time and it is therefore impossible to ascertain which articles were available to respondents in the survey, ${ }^{3}$ we opted for using the articles classified as "most read" as an approximation. For the random page, for each day the website was coded so that a random sample of the published articles in the domestic and foreign news was chosen as being part of the random page. This sampling strategy led to 4643 articles coded in 68 editions of each newspaper, 80 broadcasts of each television news program, and 80 days of the online news source (a total of 444 date-outlet combinations).

Coding was performed by ten recruited and trained student coders. The coders participated in a joint training with fellow coders. The EU performance variable was part of the Dutch coding. After the training, intercoder reliability was assessed using a none-random sample of articles from English newspapers to test the variables coded EU wide $(\mathrm{N}=16)$, and a non-random sample of articles from Dutch newspapers to test the Dutch specific variables $(\mathrm{N}=11)$. The articles were chosen such that there would be some spread on all variables. The results of the inter-coder reliability test are shown in Table $A$ in the Appendix and fall within conventional ICR standards (Riffe, Lacy, \& Fico, 1998).

\subsubsection{Content Analysis Measures}

Visibility was assessed by coders coding whether the EU or its institutions were mentioned in the article (no $=0$; yes $=1$ ). Visibility for a particular outlet and a particular period was calculated as the proportion of all articles in that period for that outlet. As for newspapers there was an oversampling of stories mentioning the EU, the proportion was only calculated for articles on the front page and the random page (as a random sample of the news).

EU evaluation was assessed by coding the number of positive and negative evaluative statements in each article. We coded evaluative statements about the EU as a whole (i.e., as a political institution) and not about specific institutions (as for instance the European Commission or the European Parliament). If the number of negative evaluations exceeded the number of positive

more left-of-centre ideology and the second being right-of-centre. Since citizens retrieve their news more and more online, we also added the most widely used online news website: www.nu.nl

${ }^{3}$ We did not consider the homepage of the news website as a front page, because online news sites do not have a unique daily homepage. The homepage is constantly changing and is also adjusted to personal preferences of the site's visitor by the use of cookies. And on a more practical note, the homepage of nu.nl lists at any given moment more than 60 titles of the most recent published articles, which should not be considered as front page material in terms of the importance of the news and also given that this is too high a number of articles compared to the front page of a physical newspapers. 
evaluations, EU evaluation was coded as -1 ; if the number of positive evaluations exceeded the number of negative evaluations, EU evaluation was coded as +1 ; if the number of positive and negative evaluations was equal (or if there were no evaluations) EU evaluation was coded as 0 . Similar to visibility, EU evaluation for a particular outlet and a particular period was calculated as the mean of all articles in that period for that outlet. The oversampling of EU articles here does not affect the randomness of the sample, because all articles concerning the EU were selected to code on randomly selected days. Thus, the mean is calculated across all articles mentioning the EU.

EU performance evaluation was assessed by coding references to the current performance of the EU. These references could be about the democratic performance of the EU, and about the quality/effectiveness of the policies of the EU. In contrast to our measure of EU evaluations, here we also coded evaluations of the performance of specific EU institutions. EU performance evaluations were coded $-1,0$ or +1 in the same way as with the general EU evaluation.

\subsubsection{Survey Measures}

To measure the different dimensions of EU attitudes, respondents were asked in each wave to self-assess their agreement, on a 7 point scale, to a multiple item scale. EU performance was measured with three items: (1) The European Union functions well as it is, (2) the European Union functions according to democratic principles, and (3) the decision-making process in the European Union is transparent. Cronbach's alpha ranged from .86 to .88 in the four waves.

Media exposure was assessed by asking respondents on how many days in a typical week did they watched or read each of the outlets. To measure exposure to the EU and to evaluations of the EU, we weighted the media exposure measure. For this, we used the visibility and evaluation scores from the content analysis. For each wave of the survey, we assessed for each outlet how visible the EU was and how it was evaluated between the waves. We linked media visibility to individual respondents by multiplying the visibility scores for each periodoutlet combination to the self-reported exposure to

${ }^{4}$ For each wave the EU visibility exposure measure $\left(X_{1}\right)$ is calculated by weighting the media exposure measure using the following equation:

$$
X_{1 i, t}=\sum_{j} \text { exposure }_{i, j, t} * \text { visibility }_{j, t}
$$

With exposure $e_{i, j, t}$ the number of days respondent $i$ reports to use outlet $j$ in a typical week at time point $t$, and visibility $y_{j, t}$ the mean visibility of the EU in outlet $j$ in the period preceding time point $t$. that outlet in the consecutive wave of the survey. For evaluation exposure we followed a similar method. ${ }^{4}$ Combining media content data with (panel) survey data is seen as one of the strongest designs for assessing media effects in observational studies (Schuck, Vliegenthart, \& de Vreese, 2016; Slater, 2004, 2015).

A number of control variables were included in the model. To test whether it is mere media exposure or whether exposure to specific content has an effect above and beyond, we added a "raw" media exposure measure, adding together the number of days respondents use each of the media outlets used in this study. The descriptive measures of this variable and all additional variables can be found in Table B in the Appendix. Additional control variables include two measures of interest, the first measuring general interest in the EU and the second measuring individual interest in the election campaign for the EP elections specifically. Also, we added two measures of interpersonal communication: Interpersonal communication about politics and interpersonal communication about the EU as covariates to the model. Finally, we added satisfaction with the current government and respondents evaluations of the economy. All items were measured on a seven-point scale and measured at the same time as the dependent and independent variable (see Table B in the Appendix for question wording).

\section{Results}

\subsection{Descriptives of Public Opinion Development}

In Figure 1 the mean values (with 95\% confidence interval) of the EU performance evaluations are plotted over time starting in April 2009 (just before the previous EP elections of 2009); the subsequent four time points represent the four waves of our survey. This finding dovetails a more general pattern showing that since 2009, Dutch citizens have become more negative in their views regarding the EU (De Vreese, Azrout, \& Moeller, in press). The drop in the performance dimension (with an aggregate level .6 drop on a 7-point scale) is the largest when compared to other attitude dimensions. A formal test showed that the difference was significant $(p<$ .001).

Similar, we calculated the EU evaluation exposure measure $\left(X_{2}\right)$ using the formula:

$$
X_{2 i}=\sum_{j} \text { exposure }_{i, j} * \text { evaluation }_{j}
$$

With $j$ representing the different media outlets, exposure $e_{i, j}$ the number of days respondent $i$ reports to use outlet $j$ in a typical week, and evaluation ${ }_{j}$ the mean evaluation of the $\mathrm{EU}$ in outlet $j$ in the period preceding the wave. 


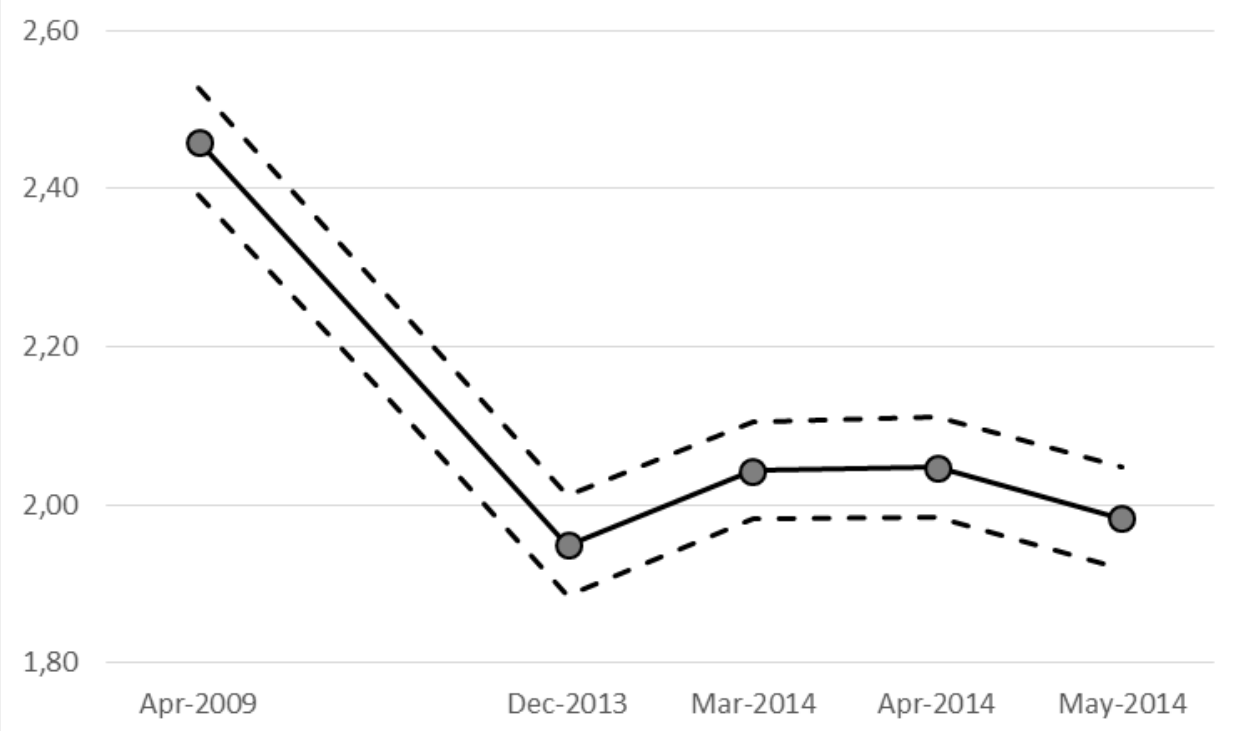

Figure 1. Mean values of EU performance evaluation by the public over time, with the $95 \%$ confidence interval.

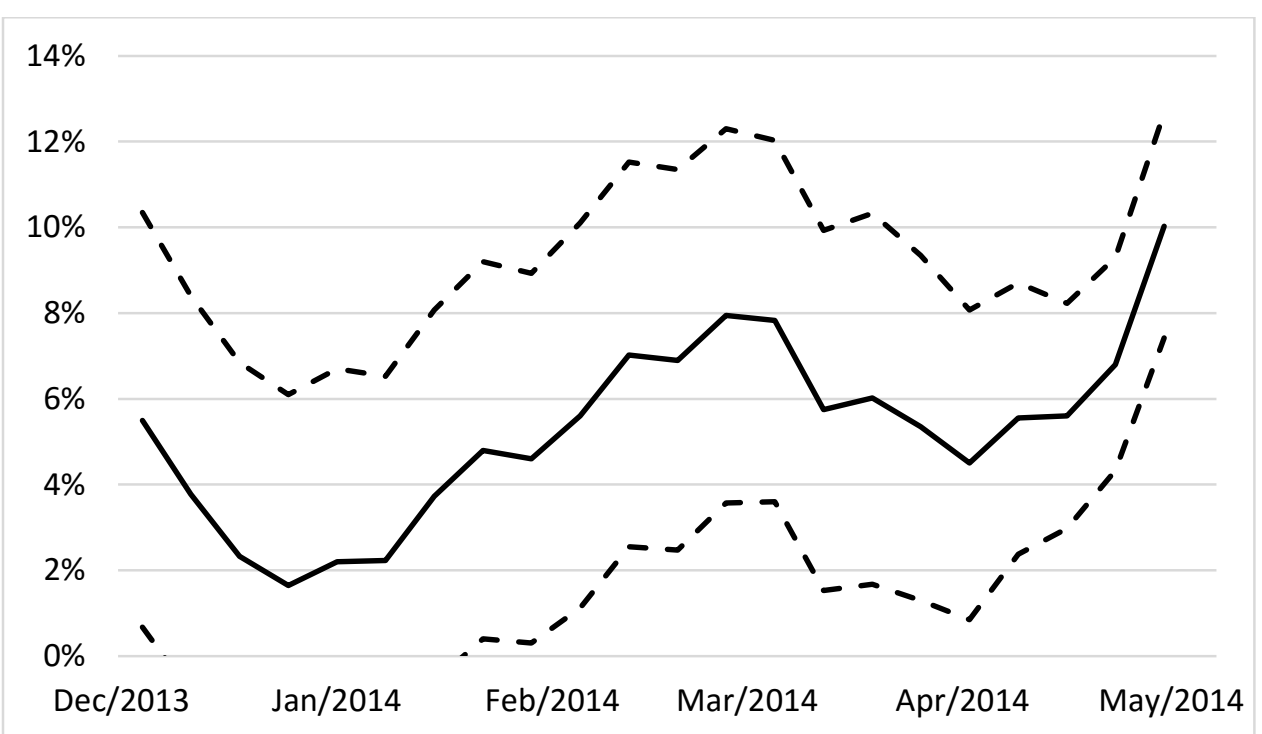

Figure 2. Over time visibility as a proportion of the number of articles mentioning the EU on the front page and the random pages. Note: To smooth out the graph, we used a moving average of 4 weeks. The dashed lines represent the $95 \%$ confidence interval.

\subsection{Descriptives Media Coverage}

In order to understand the dynamic relationship of media coverage and attitude formation it is useful to describe the development over time in media coverage and attitude formation separately. With regard to media coverage two characteristics are of importance in this study: visibility and evaluation.

\subsubsection{EU Visibility}

Figure 2 shows how visible the EU was over time between December 2013 and the elections in 2014 (taking all outlets together). The EU was least visible in January 2015 (less than $2 \%$ of the news coverage). The visibility of the EU steadily increases over time, but drops again a little in April of that same year, and increases again as the June elections draw nearer. Comparing the different outlets (see Figure 3), we see substantial differences in EU visibility across the different newspapers. In particular, the tabloid (de Telegraaf) and television news programs (public and commercial) score lowest in EU visibility. The online news source nu.nl scores highest in our analysis, but this is likely due to different sampling strategies. 


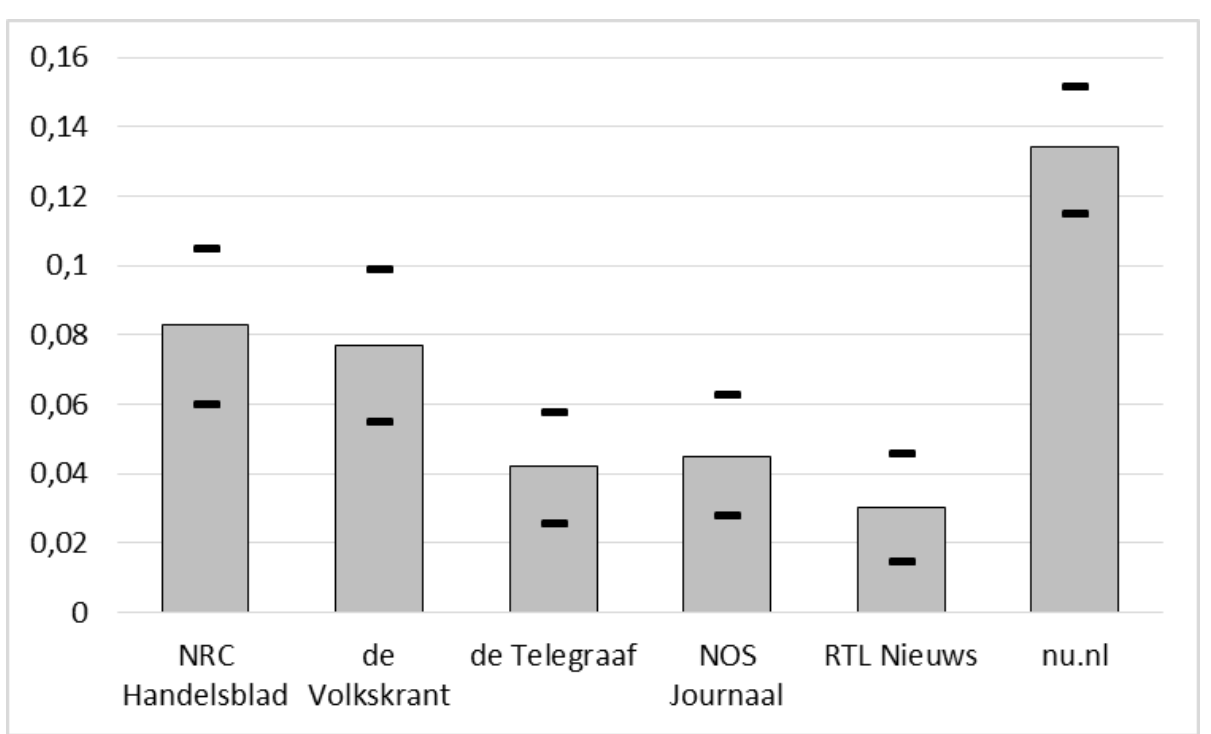

Figure 3. Visibility per news outlet, as the proportion of articles mentioning the EU on the front page and the random page (including the $95 \%$ confidence interval).

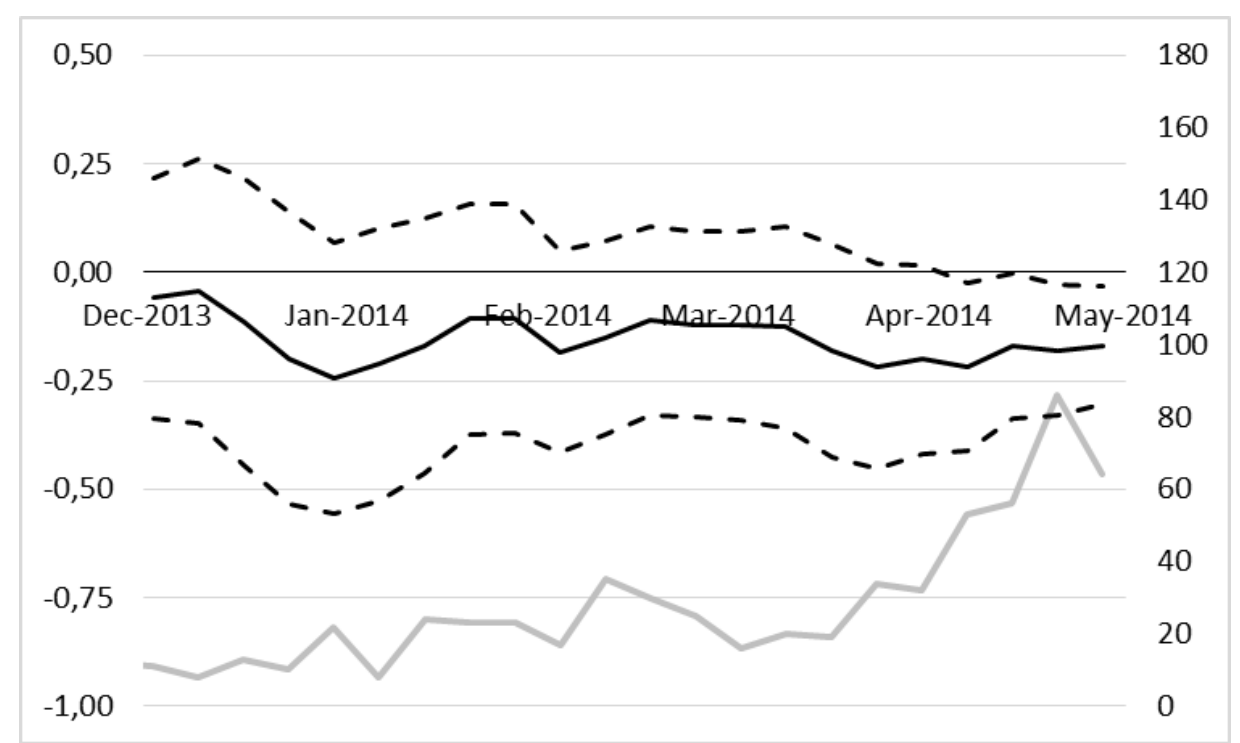

Figure 4. Average EU evaluations over time. Note: The left axis represents values of EU evaluations, with the black solid line representing the mean evaluation over time (and the dashed line representing the $95 \%$ confidence interval). To smooth out the line, we used a moving average of 4 weeks. The grey line represents the number of news stories each week, with the scale shown on the right axis (no moving average).

\subsubsection{EU and Performance Evaluations}

Figure 4 shows the development of EU evaluations over time. Our results indicate that the general EU evaluation is, on average, always a negative evaluation. Yet, evaluations are generally close to zero and with the exception of the final month, the $95 \%$ confidence interval includes the neutral value. But we should note that, given the number of coded articles about the EU in each week, this is most likely due to insufficient statistical power. In a similar fashion, the negative peaks observed in January are likely the result of the small number of articles (considering the low visibility of the EU in January), whereby a few extreme articles have substantial influence.
Plotted in Figure 5, the performance indicator also shows that evaluations are, on average, negative over the entire period, only reaching statistical significance at the end of our sampling period (this again is likely due to a lack of statistical power). Also, positive (February) and negative peaks (April) are the result of limited coverage in the weeks before, with "extreme" performance evaluations. EU evaluations also differed across news outlets (see Figure 6). General EU evaluations were most negative in tabloid newspapers (De Telegraaf), while nu.nl (the online news source) is the least negative. These differences are, however, small and not significant. But we do observe that all outlets show on average (minor) negative evaluations. 


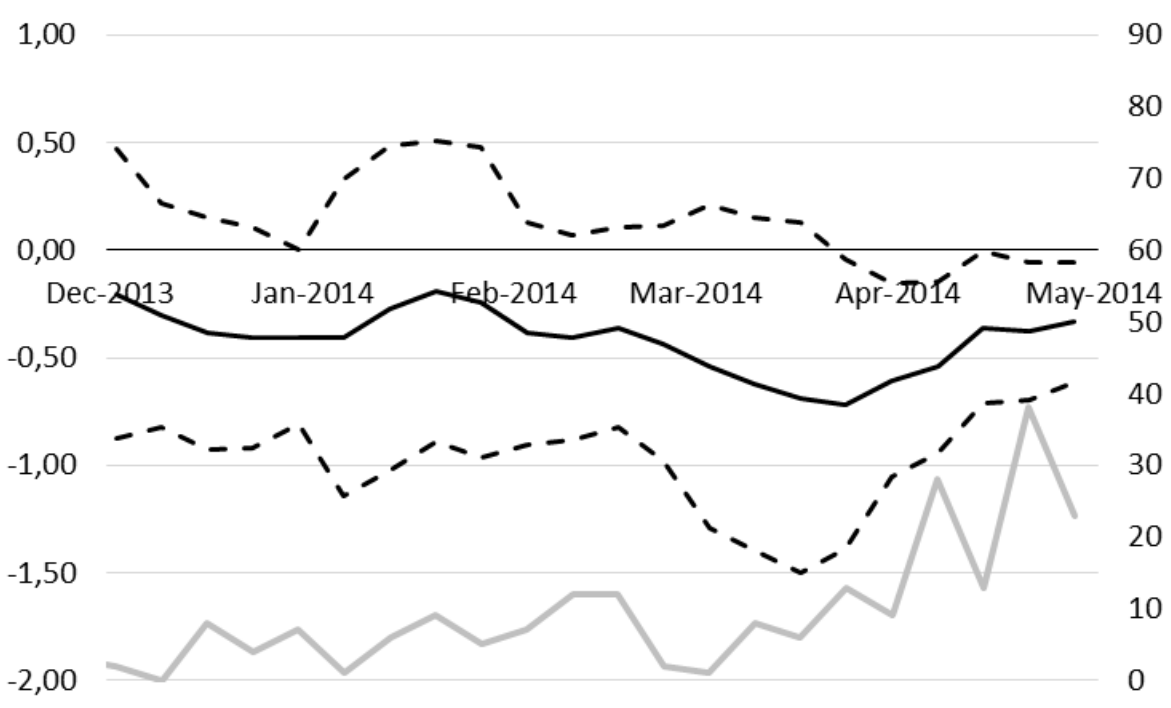

Figure 5. Average performance evaluations over time. Note: The left axis represents values of EU performance evaluations, with the black solid line representing the mean evaluation over time (and the dashed line representing the $95 \%$ confidence interval). To smooth out the line, we used a moving average of 4 weeks. The grey line represents the number of news stories each week, with the scale shown on the right axis (no moving average).

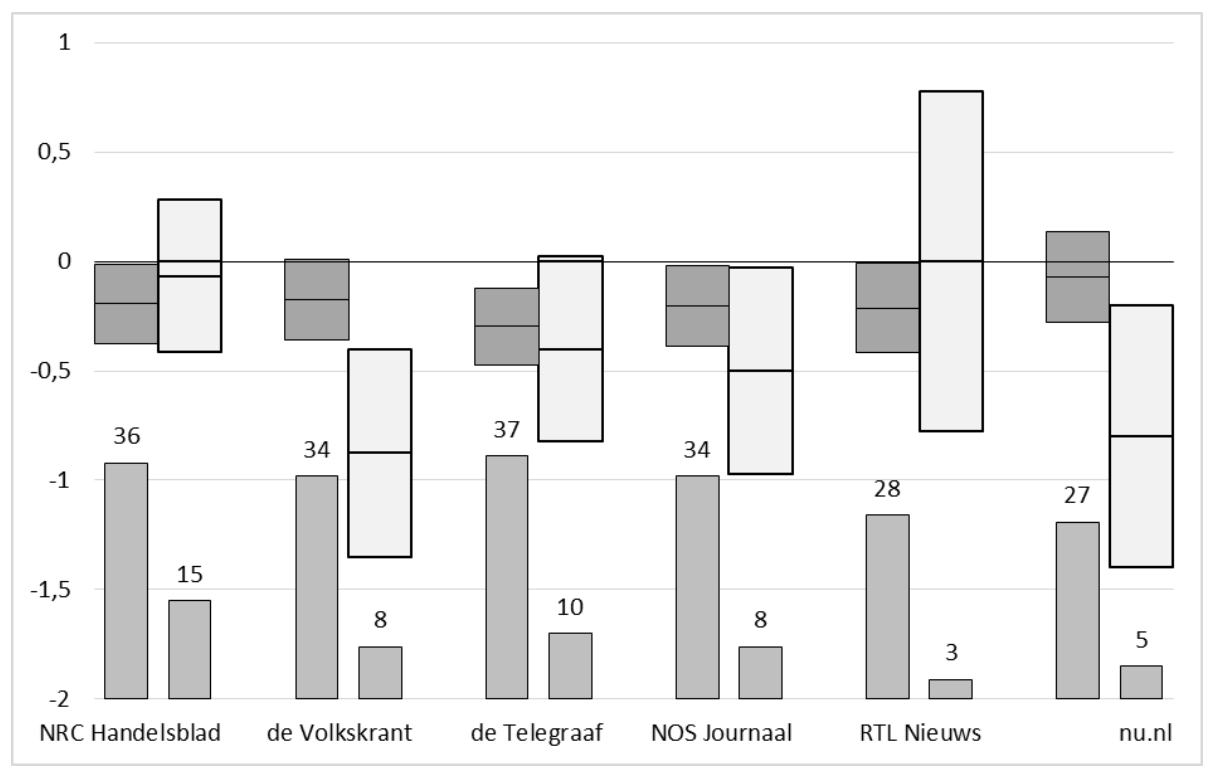

Figure 6. EU and performance evaluations per news outlet. Note: The darker grey bars represent EU evaluations and the lighter grey bars represent performance evaluations, with the middle of the bar representing the mean per outlet and the length of the bar representing the $95 \%$ confidence interval. The bars at the bottom represent the number of news stories the mean is based on.

A similar pattern emerges for performance evaluations, however in this case De Volkskrant is found to be the most negative and RTL Nieuws the least negative. However, we need to note that many of these more detailed results are calculated on the basis of a very small set of articles that featured performance evaluations. For example, RTL Nieuws' coverage of the EU featured only 3 stories in 6 months that mentioned EU performance. Similar to the general EU evaluations, performance had an overall (though minor) negative evaluation, with no significant differences between newspapers.

\subsection{Explanatory Analyses of EU Performance Dimension}

We now turn to analysing factors influencing change in EU performance evaluations of Dutch citizens using multi-level panel modelling, in particular the influence of media exposure to stories about the EU and evaluations of the EU and its performance. Table 1 shows the results of predicting change in EU performance evaluations using fixed effects modelling. We use a fixed effects model to explain within-subject change in the dependent variable with within-subject change in the 
independent variables, i.e., we compare each respondent with him/herself at an earlier time point (e.g., Allison, 2009). The advantage of this approach is that the models implicitly control for all time-invariant factors like gender or stable character traits and thus do not need to be added to the models. Additionally, we control for interest in the EU and the EP elections campaign, interpersonal communication, government satisfaction and economic evaluations, as these are both likely to change over time and are likely related to both media exposure and EU performance evaluations.

The first model in Table 1 is a baseline model, with all the controls added but without weighted media exposure measures. We observe that raw news exposure has a significant negative effect on EU performance evaluations $(b=-0.010$, se $=0.001, p<.001)$. Adding EU performance exposure (see model 2 ) significantly improves the model $\left(\chi^{2}(\mathrm{df}=1)=5.987, p=.014\right)$ and we find a positive significant effect of EU performance exposure $(b=0.241$, se $=0.099, p=.014)$. Thus, more exposure to EU performance in the news leads to a more positive evaluation of EU performance.

To give a more substantial interpretation, we need to consider that the EU performance exposure variable can vary by change in amount of media used by an individual and by change in the amount of coverage about EU performance in each outlet. To illustrate the different impact of media coverage and media use, we plotted the expected change in EU performance evaluations against change in media use and change in media content in the two panels of Figure 7.

In the first panel of Figure 7, we show the predicted change in EU performance evaluations when media use exposure changes while keeping measures of media content constant. Because the impact of increase in media use also depends on the amount of coverage on EU performance, we added three lines to the graph, indicating the impact when frequency of media coverage is held constant at the mean (the solid line), the mean minus one standard deviation (the dotted line), and the mean plus the standard deviation (the dashed line). The first panel thus shows that when average news users increase their use of a media outlet by one standard deviation, our model predicts a positive change in EU performance evaluations of 0.026 . Yet, we need to consider that this is the predicted impact of change in use of one

Table 1. Fixed effects models explaining EU performance attitudes using exposure to EU performance visibility and evaluation in the media.

\begin{tabular}{|c|c|c|c|c|}
\hline & 1 & 2 & 3 & 4 \\
\hline \multirow{2}{*}{ Intercept } & 0.018 & 0.043 & 0.022 & 0.043 \\
\hline & $(0.068)$ & $(0.069)$ & $(0.069)$ & $(0.069)$ \\
\hline \multirow[t]{2}{*}{ Wave 2} & $0.067^{*}$ & $0.074^{*}$ & $0.060^{+}$ & $0.073^{*}$ \\
\hline & $(0.031)$ & $(0.031)$ & $(0.035)$ & $(0.035)$ \\
\hline \multirow[t]{2}{*}{ Wave 3} & $0.054^{+}$ & $0.055^{+}$ & 0.047 & 0.054 \\
\hline & $(0.030)$ & $(0.030)$ & $(0.034)$ & $(0.034)$ \\
\hline \multirow[t]{2}{*}{ Wave 4} & 0.006 & -0.043 & 0.001 & -0.044 \\
\hline & $(0.025)$ & $(0.032)$ & $(0.027)$ & $(0.033)$ \\
\hline \multirow[t]{2}{*}{ Raw news exposure } & $-0.010^{* * *}$ & $-0.012^{* * *}$ & $-0.010^{* * *}$ & $-0.012^{* * *}$ \\
\hline & $(0.002)$ & $(0.003)$ & $(0.003)$ & $(0.003)$ \\
\hline \multirow[t]{2}{*}{ Interest EU } & $0.075^{* * *}$ & $0.075^{* * *}$ & $0.075^{* * *}$ & $0.075^{* * *}$ \\
\hline & $(0.010)$ & $(0.010)$ & $(0.010)$ & $(0.010)$ \\
\hline \multirow[t]{2}{*}{ Interest EPE campaign } & $0.037^{* * *}$ & $0.036^{* * *}$ & $0.037^{* * *}$ & $0.036^{* * *}$ \\
\hline & $(0.009)$ & $(0.009)$ & $(0.009)$ & $(0.009)$ \\
\hline \multirow[t]{2}{*}{ IPC politics } & $-0.032^{* *}$ & $-0.033^{* *}$ & $-0.032^{* *}$ & $-0.033^{* *}$ \\
\hline & $(0.012)$ & $(0.012)$ & $(0.012)$ & $(0.012)$ \\
\hline \multirow[t]{2}{*}{ IPC EU } & -0.001 & -0.001 & -0.001 & -0.001 \\
\hline & $(0.013)$ & $(0.013)$ & $(0.013)$ & $(0.013)$ \\
\hline \multirow[t]{2}{*}{ Government satisfaction } & $0.297^{* * *}$ & $0.296^{* * *}$ & $0.297^{* * *}$ & $0.296^{* * *}$ \\
\hline & $(0.015)$ & $(0.015)$ & $(0.015)$ & $(0.015)$ \\
\hline \multirow[t]{2}{*}{ Economic evaluations } & $0.214^{* * *}$ & $0.213^{* * *}$ & $0.215^{* * *}$ & $0.213^{* * *}$ \\
\hline & $(0.016)$ & $(0.016)$ & $(0.016)$ & $(0.016)$ \\
\hline \multirow[t]{2}{*}{ Exposure performance visibility } & & $0.241^{*}$ & & $0.241^{*}$ \\
\hline & & (0.099) & & $(0.100)$ \\
\hline \multirow[t]{2}{*}{ Exposure performance tone } & & & -0.002 & -0.000 \\
\hline & & & $(0.004)$ & $(0.004)$ \\
\hline$-2 L L$ & 17465.821 & 17459.834 & 17465.584 & 17459.833 \\
\hline $\mathrm{AIC}$ & 17491.821 & 17487.834 & 17493.584 & 17489.833 \\
\hline
\end{tabular}


Panel 1: Change in EU performance by change (in SD) in media use

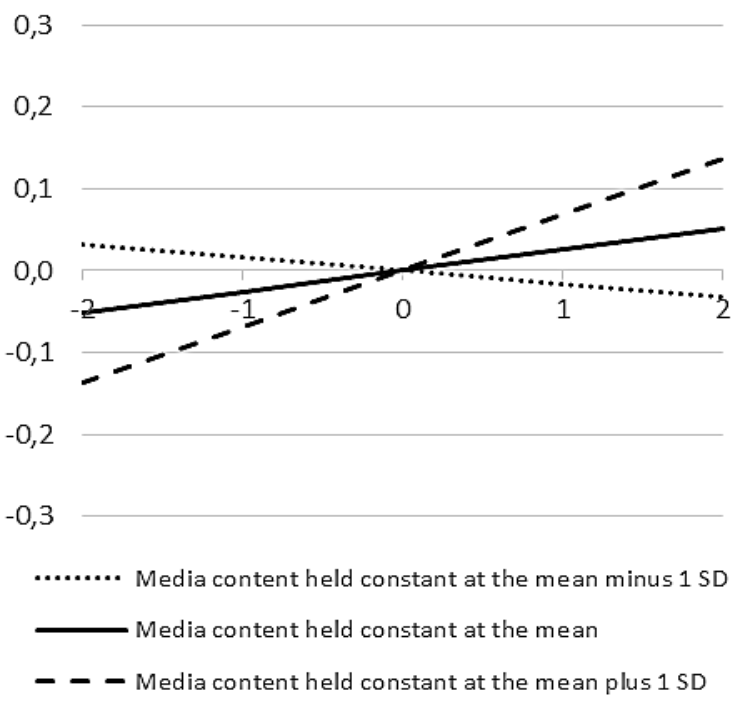

Panel 2: Change in EU performance by change (in SD) in media content

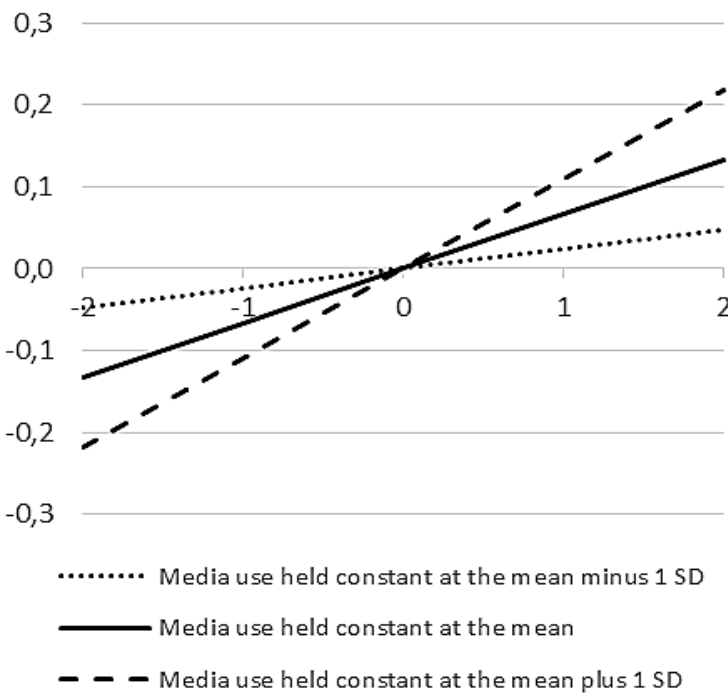

Figure 7. The graphs represent the expected change in EU performance evaluations based on the model. In the left panel, the expected change is shown while keeping the media content constant (represented by the three different lines, keeping the media constant at three different levels) and by change in standard deviations in media use (represented in the $\mathrm{x}$-axis). In the right panel, media use is kept constant, while varying EU visibility in the media content.

average media outlet. If a respondent would increase his/her use of all media outlets by one standard deviation, the model predicts an increase in EU performance evaluations of 0.157 .

In the second panel of Figure 7 we show the predicted change in EU evaluations by change in media content, while keeping measures of media use constant. The graph shows that if a media outlet started to feature one standard deviation more coverage of the EU, average users of that outlet are predicted to move 0.067 item steps towards positive performance evaluations. Again this is quite a modest change, but for a heavy user (plus one standard deviation), the model predicts a change of .109; and if all outlets would increase their coverage by one standard deviation, the EU performance evaluation of an average media user is expected to increase by .400 . Comparing the first and second panel we see that, within the variation we find in our sample, change in media coverage has a stronger impact than change in media use.

Exposure to EU performance evaluations does not seem to affect citizens' general evaluations of EU performance, with (see model 4) or without (see model 3) exposure to EU performance visibility in the model. Adding exposure to evaluations to the model does not improve the model (comparing model 3 to model $1: \chi^{2}(\mathrm{df}=1)=0.237$, $p=.626$; comparing model 4 to model $2: \chi^{2}(\mathrm{df}=1)=0.002, p$ $=.966)$, nor does evaluation exposure have a significant effect (model 3: $b=-0.002$, se $=0.004, p=.626$; model 4: $b=-0.000$, se $=0.004, p=.966$ ). We do see that the effect of exposure to EU performance visibility remains significant when adding exposure to evaluations to the model, and is of comparable size $(b=0.241$, se $=0.100, p=.016)$. Thus, respondents are affected by whether the news they consume reports about EU performance, but not by exposure to general media evaluations.

\section{Discussion}

Corroborating general and popular impressions, it is safe to say that public opinion-including in the Netherlands-became more negative towards the EU and European integration between 2009 and 2013. The decrease in support is observed across-the-board (De Vreese et al., 2016), but the greatest magnitude is for the performance dimension. Turning to the media, the analysis of the news coverage suggests that EU topics were not highly salient in the news during the six-month period though direct comparisons are difficult, since from previous research we know most about the final weeks before the election (e.g., Schuck et al., 2011). Considering the increased stakes of the EP elections in 2014, it is perhaps surprising that media salience was not higher. The elected parliament gained significant influence, for example in the right to (co-)appoint the President of the European Commission. Moreover, the Dutch campaign much like the British campaign, was characterized by heated debates about the EU that featured strong Anti-EU parties. Yet, coverage on the EU only made up $2 \%$ of the coverage in the political section over the course of six months, which means that the EU was largely invisible to most Dutch citizens in the period leading up to the elections. In line with previous research we find that EU news is either neutral or slightly negative. 
In terms of development in EU attitudes-as a function of exposure to news during the period of analysiswe focused on the performance dimension and, by combining detailed content analysis data with panel survey data, found positive effects of exposure to news that was less negative (see also de Vreese \& Boomgaarden, 2016). This combination of data and its linkage at the individual level are among the closed approximations of media effects in an observational setting (Slater, 2004, 2015). Using these detailed exposure measures that allow to pinpoint exposure to specific content and identifying effects of this exposure, while simultaneously controlling for all time-invariant factors like general political interest, is one advantage of our design.

Another noteworthy finding of our study is that even though coverage about the performance of the EU was rather negative, exposure to this coverage has a positive effect on attitudes towards the performance of the European Union. Although this finding seems counter-intuitive, there are two explanations that might explain this observation. First, regardless of the evaluation, coverage about the performance of the EU means that media users are exposed to news items about functioning institutions that actively shape policy in the European context. In contrast to other news items about the EU that cover the EU from a national perspective, news items about the performance of the EU portray European institutions as a supra-national actor that has the potential to bring about change. This could lead to a more positive evaluation of the performance of these EU institutions. On a more general level this is an example of how seeing the "EU in action" in the news mitigates the overall negative developments otherwise found in EU attitudes. Second, when comparing the evaluation of the different dimensions in the news coverage, it becomes apparent that performance was evaluated less negatively than other dimensions. This means that the performance of the EU stood out as one of the more successful dimensions of the EU in contrast to other dimensions. Our results here are only partially in line with the work by Desmet et al. (2015) who did find effects of evaluative news. They found that when news tone converges and creates a one-sided evaluative news coverage, whether positive or negative, this affects individual EU evaluations. Future research should further explicate the conditions under which visibility or evaluations constitute the driving effect.

We believe that our Dutch case study is an interesting case to learn from because public opinion is variable with respect to the EU. More importantly, regardless of the absolute level of EU evaluation in a specific case, we believe we may draw inferences about the underlying dynamics we are studying beyond the Dutch case.

Taking a step back we believe that our study is informative for research looking at the democratic deficit of the EU and current EU developments. In past research we have seen how national yardsticks are important for evaluating the EU. Desmet et al. (2012) and Hobolt (2012) both demonstrated this empirically and cross-nationally. As the EU takes more of a centre stage in politics - and as citizens in turn become more aware of the functioning of the EU and its institutions-the evaluations of the performance of the EU is likely to not only carry more weight for general opinions about the EU and EU democracy, but perhaps also for domestic politics and democracy. This dynamic hints at what van der Eijk and Franklin (2004) dubbed the 'sleeping giant' (see also de Vries, 2007) more than a decade ago, referring to the potential ability of EU politics to shape national politics. Indeed recent evidence (Miklin, 2014) suggests that in the wake of the crisis, the saliency of European issues has increased (although the incentive structure is still such that for mainstream parties it can be more functional to suppress EU topics).

Our study also shows that EU attitudes are quite subject to change. This may happen during an election campaign or over a longer period of time in response to both real world developments and media coverage (see also Van Klingeren, Boomgaarden, Vliegenthart, \& de Vreese, 2015). This is informative as scholarship on EU public opinion moves forward: 2014 might have been a cross-road election, but much of what shaped the particular dynamics of that campaign started much earlier.

\section{Acknowledgments}

The authors wish to thank ASCoR for co-funding the study and the participants of the ACCESS EUROPE workshop on "The European Elections 2014" as well as the anonymous reviewers for their helpful comments and suggestions.

\section{Conflict of Interests}

The authors declare no conflict of interests.

\section{References}

Allison, P. (2009). Fixed effects regression models. Los Angeles: Sage Publications.

Alvarez, R. M., \& Franklin, C. H. (1994). Uncertainty and political perceptions. The Journal of Politics, 56(3), 671-688.

Anderson, C. J., \& Guillory, C. A. (1997). Political institutions and satisfaction with democracy: A cross-national analysis of consensus and majoritarian systems. American Political Science Review, 91(1), 66-81.

Azrout, R., van Spanje, J., \& de Vreese, C. H. (2012). When news matters: Media effects on public support for EU enlargement in 21 countries. Journal of Common Market Studies, 50(5), 691-708.

Boomgaarden, H. G., Schuck, A. R. T., Elenbaas, M., \& de Vreese, C. H. (2011). Mapping EU attitudes: Conceptual and empirical dimensions of Euroskepticism and 
EU support. European Union Politics, 12(2), 241-266.

de Vreese, C. H., Azrout, R., \& Möller, J. (2014). 2014 European Parliament election campaign study: Data and documentation. Amsterdam: University of Amsterdam

de Vreese, C. H., Azrout, R., \& Moeller, J. (in press). From Europhile to Euroskeptic? The changing nature of public opinion in the Netherlands. In M. Franklin \& J. $\mathrm{H}$. Nielsen (Eds.), A lens on Euroscepticism: The impact of Eurosceptic attitudes on the 2014 European Parliament elections. Palgrave Studies in European Union Politics

de Vreese, C. H., \& Boomgaarden, H. G. (2016). Effects of news media coverage on public support for European integration. In W. van der Brug \& C. H. de Vreese (Eds.), (Un)intended consequences of European Parliamentary Elections. Oxford: Oxford University Press.

de Vreese, C. H., Banducci, S. A., Semetko, H. A., \& Boomgaarden, H. G. (2006). The news coverage of the 2004 European Parliamentary election campaign in 25 countries. European Union Politics, 7(4), 477-504.

de Vreese, C. H., \& van der Brug, W. (2016). Conclusion. In W. van der Brug \& C. H. de Vreese (Eds.), (Un)intended consequences of European Parliamentary elections. Oxford: Oxford University Press.

de Vries, C. E. (2007). Sleeping giant: Fact or fairytale? How European integration affects national elections. European Union Politics, 8(3), 363-385.

Desmet, P., van Spanje, J., \& de Vreese, C. H. (2012). 'Second-order' institutions: National institutional quality as a yardstick for EU evaluation. Journal of European Public Policy, 19(7), 1071-1088.

Desmet, P., van Spanje, J., \& de Vreese, C. (2015). European public sphere. Discussing the democratic deficit: Effects of media and interpersonal communication on satisfaction with democracy in the European Union. International Journal of Communication, 9(22), 31773198.

Easton, D. (1975). A re-assessment of the concept of political support. British Journal of Political Science, 5(4), 435-457.

Gabel, M. J. (1998). Public support for European integration: An empirical test of five theories. Journal of Politics, 60(2), 333-354.

Hewstone, M. (1986). Understanding attitudes towards the European community. New York: Cambridge University Press.

Hobolt, S. B. (2012). Citizen satisfaction with democracy in the European Union. Journal of Common Market Studies, 50(1), 88-105.

Hobolt, S. B. (2014) Ever closer or ever wider? Public attitudes towards further enlargement and integration in the European Union. Journal of European Public Policy, 21(5), 664-680.

Hooghe, L., \& Marks, G. (2005). Calculation, community, and cues: Public opinion on European integration. European Union Politics, 6(4), 421-445.
Hopmann, D. N., Vliegenthart, R., De Vreese, C., \& Albæk, E. (2010). Effects of election news coverage: How visibility and tone influence party choice. Political Communication, 27(4), 389-405.

Karp, J. A., Banducci, S. A., \& Bowler, S. (2003). To know it is to love it? Satisfaction with democracy in the European Union. Comparative Political Studies, 36(3), 271292.

Klingemann, H. -D., \& Fuchs, D. (1995). Citizens and the state. Oxford: Oxford University Press.

Lewis-Beck, M. S. (1988). Economics and the American voter: Past, present, future. Political Behavior, 10(1), $5-21$.

Lindberg, L. N., \& Scheingold, S. A. (1970). Europe's would-be polity: Patterns of change in the European community. Upper Saddle River, NJ: Prentice Hall.

Maier, J., \& Rittberger, B. (2008). Shifting Europe's boundaries: Mass media, public opinion and the enlargement of the EU. European Union Politics, 9(2), 243267.

Majone, G. (1998). Europe's "democratic deficit": The question of standards. European Law Journal, 4(1), 528.

Majone, G. (2000). The credibility crisis of community regulation. Journal of Common Market Studies, 38(2), 273-302.

Miklin, E. (2014). From 'sleeping giant' to left-right politicization? National party competition on the EU and the Euro Crisis. Journal of Common Market Studies, 52(6), 1199-1206.

Norris, P. (1999). Critical citizens: Global support for democratic governance. Oxford: Oxford University Press.

Riffe, D., Lacy, S., \& Fico, F. G. (1998). Analyzing media messages: Using quantitative content analysis in research. Mahwah, NJ: Lawrence Erlbaum.

Rohrschneider, R. (2002). The democracy deficit and mass support for an EU-wide government. American Journal of Political Science, 46(2), 463-475.

Rose, R., \& Mishler, W. (2002). Comparing regime support in non-democratic and democratic countries. Democratization, 9(2), 1-20.

Sanchez-Cuenca, I. (2000). The political basis of support for European integration. European Union Politics, 1(2), 147-171.

Scharpf, F. (1999). Governing in Europe: Effective and democratic? Oxford: Oxford University Press.

Scheuer, A. (2005). How Europeans see Europe: Structure and dynamics of European legitimacy beliefs. Amsterdam: Vossiuspers UvA.

Schuck, A. R. T., Azrout, R., Boomgaarden, H. G., Elenbaas, M., van Spanje, J., Vliegenthart, R., \& de Vreese, C. H. (2011). Media visibility and framing of the European Parliamentary Elections 2009: A media content analysis in 27 countries. In M. Maier, J. Strömbäck, \& L. L. Kaid (Eds.), Campaigning in Europe: Strategies, effects, and media coverage in European Parliamentary elections. Farnham: Ashgate Publishing Limited. 
Schuck, A. R. T., Vliegenthart, R., \& de Vreese, C. H. (2016). Who's afraid of conflict? The mobilizing effect of conflict framing in campaign news. British Journal of Political Science, forthcoming.

Slater, M. D. (2004). Operationalizing and analyzing exposure: The foundation of media effects research. Journalism and Mass Communication Quarterly, 81, 168183.

Slater, M. D. (2015). Reinforcing spirals model: Conceptualizing the relationship between media content exposure and the development and maintenance of attitudes and social identity. Media Psychology, 18, 370395

Stokes, S. (2001). Public opinion of market reform: A framework. In S. Stokes (Ed.), Public support for market reforms in new democracies (pp. 1-32). Cambridge: Cambridge University Press.

Tilley, J., \& Hobolt, S. (2011). Is the government to blame? An experimental test of how partisanship shapes perceptions of performance and responsibility. Journal of Politics, 73(2), 316-330.
Treib, O. (2014). The voter says not, but nobody listens: Causes and consequences of the Euroskeptic vote in the 2014 European elections. Journal of European Public Policy, 21(10), 1541-1554. doi:10.1080/135 01763.2014.941534

van der Eijk, C., \& Franklin, M. N. (2004). Potential for contestation on European matters at national elections in Europe. In G. Marks \& M. R. Steenbergen (Eds.), European integration and political conflict. Cambridge: Cambridge University Press.

van Klingeren, M., Boomgaarden, H. G., Vliegenthart, R., \& de Vreese, C. H. (2015). Real world is not enough: The media as an additional source of negative attitudes towards immigration. European Sociological Review, 31(3), 268-283.

van Spanje, J., \& de Vreese, C. H. (2014). Europhile media and eurosceptic voting: Effects of news media coverage on euroskeptic voting in the 2009 European Parliamentary elections. Political Communication, 31, 325-354.

\section{About the Authors}

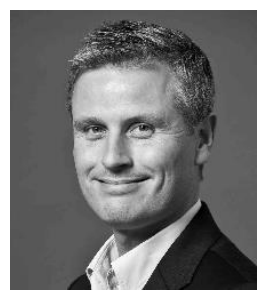

\section{Dr. Claes de Vreese}

Claes de Vreese is Professor and Chair of Political Communication at ASCoR at the University of Amsterdam. He is the founding Director of Center for Politics and Communication (www.polcomm.org). His research interests focus on political journalism, media effects, public opinion and electoral behaviour. His most recent (co-authored) books are Political Journalism in Comparative Perspective (Cambridge UP) and (Un)intended Consequences of European Parliament Elections (Oxford UP).

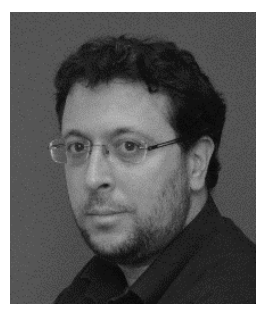

\section{Dr. Rachid Azrout}

Rachid Azrout is a researcher of Political Communication at the Department of Communication Science at the University of Amsterdam. His research focuses on public opinion and media effects, with a special interest on minority issues and the European Union.



\section{Dr. Judith Moeller}

Judith Moeller is a Postdoctoral researcher at the Amsterdam School of Communication Research. In her research she focuses on the effects of political communication, with an emphasis on effects on adolescents and young adults. She is also interested in comparative research in political communication. 


\section{Appendix}

Table A. Reliability scores CA variables.

\begin{tabular}{lc}
\hline & Holsti \\
\hline EU visibility & 0.92 \\
EU evaluation & 0.61 \\
EU performance evaluation & 0.65 \\
\hline
\end{tabular}

Note: Reliability scores EU visibility and EU evaluation are based on 16 articles; reliability scores EU performance evaluation is based on 11 articles.

Table B. Descriptive measures of the control variables.

\begin{tabular}{|c|c|c|c|c|}
\hline & & $\mathbf{N}$ & M & SD \\
\hline Raw news exposure "In a typical week, how many days do you watch the & $\mathrm{t}=1$ & 2189 & 9,56 & 6,08 \\
\hline following TV programs/read the following newspapers and magazines or listen to & $t=2$ & 1819 & 9,79 & 6,02 \\
\hline the news on the radio/read about politics on the Internet through one of the & $t=3$ & 1537 & 9,38 & 6,05 \\
\hline following sources?" & $\mathrm{t}=4$ & 1379 & 9,30 & 6,16 \\
\hline Interest EU: "How interested are you in the following themes? The European & $t=1$ & 2189 & 3,38 & 1,61 \\
\hline \multirow[t]{3}{*}{ 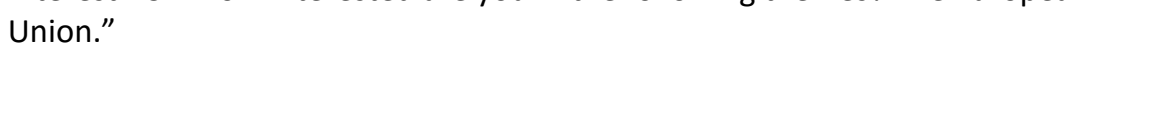 } & $t=2$ & 1819 & 3,28 & 1,57 \\
\hline & $t=3$ & 1537 & 3,09 & 1,52 \\
\hline & $\mathrm{t}=4$ & 1379 & 3,04 & 1,60 \\
\hline Interest EPE campaign: “Elections for the European Parliament are (/were) held in & $t=1$ & 2189 & 3,39 & 1,72 \\
\hline \multirow[t]{3}{*}{ May 2014. How interested are you in these elections?" } & $t=2$ & 1819 & 3,46 & 1,75 \\
\hline & $t=3$ & 1537 & 3,32 & 1,73 \\
\hline & $t=4$ & 1379 & 3,32 & 1,87 \\
\hline \multirow{4}{*}{$\begin{array}{l}\text { IPC politics: "How often do you talk about politics with family, friends, or } \\
\text { colleagues?" }\end{array}$} & $t=1$ & 2189 & 3,44 & 1,55 \\
\hline & $t=2$ & 1819 & 3,61 & 1,55 \\
\hline & $t=3$ & 1537 & 2,79 & 1,37 \\
\hline & $\mathrm{t}=4$ & 1379 & 3,06 & 1,48 \\
\hline \multirow{4}{*}{$\begin{array}{l}\text { IPC EU: "How often do you talk about the European Union with family, friends, or } \\
\text { colleagues?" }\end{array}$} & $t=1$ & 2189 & 2,57 & 1,42 \\
\hline & $t=2$ & 1819 & 2,59 & 1,41 \\
\hline & $t=3$ & 1537 & 2,18 & 1,22 \\
\hline & $\mathrm{t}=4$ & 1379 & 2,41 & 1,36 \\
\hline
\end{tabular}

Table B. Continued.

\begin{tabular}{|c|c|c|c|c|c|c|}
\hline & & Eigenvalue & Cronbach's alpha & $\mathbf{n}$ & $M$ & SD \\
\hline \multirow{8}{*}{$\begin{array}{l}\text { Economic evaluations (1-7 scale, high value is } \\
\text { positive evaluation): } \\
\text { (1) “Looking at the economic situation in the } \\
\text { Netherlands, do you think the situation will be } \\
\text { better or worse twelve months from now?" } \\
\text { (2) “How about if you think of the European Union, } \\
\text { do you think that twelve months from now the } \\
\text { economic situation in the EU will be better or } \\
\text { worse?" } \\
\text { (3) “How about your personal situation: Do you } \\
\text { think that twelve months from now your personal } \\
\text { economic situation will be better or worse?" }\end{array}$} & $t=1$ & 2.24 & 0.83 & 2189 & 3.80 & 1.05 \\
\hline & $t=2$ & 2.19 & 0.82 & 1819 & 3.94 & 0.98 \\
\hline & $t=3$ & 2.32 & 0.85 & 1537 & 3.95 & 1.03 \\
\hline & $t=4$ & 2.31 & 0.85 & 1379 & 3.91 & 1.03 \\
\hline & & & & & & \\
\hline & & & & & & \\
\hline & & & & & & \\
\hline & & & & & & \\
\hline \multirow{4}{*}{$\begin{array}{l}\text { Government satisfaction (1-7 scale, high value is } \\
\text { positive evaluation): } \\
\text { (1) "The current national government is doing a } \\
\text { good job." } \\
\text { "And how well do you think the government is } \\
\text { handling the issue of...(2) European integration; (3) } \\
\text { the economy; (4) the environment; (5) } \\
\text { immigration. }\end{array}$} & $t=1$ & 3.26 & 0.87 & 2189 & 3.17 & 1.06 \\
\hline & $t=2$ & 3.22 & 0.86 & 1819 & 3.21 & 1.05 \\
\hline & $t=3$ & 3.42 & 0.88 & 1537 & 3.26 & 1.10 \\
\hline & $t=4$ & 3.46 & 0.89 & 1379 & 3.25 & 1.10 \\
\hline
\end{tabular}

